\title{
Evaluation the Mechanical Properties of Kaolin Particulate Reinforced Epoxy Composites
}

\author{
Jabbar Hussein Mohmmed \\ Department of Materials Engineering / University of Technology/ Baghdad \\ Email: Jabbaraljanaby@ yahoo.com
}

(Received 26 March 2017; accepted 3 August 2017)

https://doi.org/10.22153/kej.2018.08.003

\begin{abstract}
Epoxy resin has many chemical features and mechanical properties, but it has a small elongation at break, low impact strength and crack propagation resistance, i.e. it exhibits a brittle behavior. In the current study, the influence of adding kaolin with variable particle size on the mechanical properties (flexural modulus E, toughness Gc, fracture toughness Kc, hardness $\mathrm{HB}$, and Wear rate WR) of epoxy resin was evaluated. Composites of epoxy with varying concentrations $(0,10,20,30,40$ weights $\%)$ of kaolin were prepared by hand-out method. The composites showed improved (E, Gc, Kc, HB, and WR) properties with the addition of filler. Also, similar results were observed with the decrease in particle size. In addition, in this study, multiple regression models were developed by utilizing (SPSS) package to predict the properties of kaolin reinforced epoxy composites. Good agreement was obtained between the predicted and the experimental results. The accuracy of prediction was $(89.71 \%, 80.58 \%, 85.82 \%, 92.27 \%$, and $94.49 \%$ ) for $\mathrm{E}, \mathrm{Gc}, \mathrm{Kc}, \mathrm{HB}$, and WR, respectively.
\end{abstract}

Keywords: Epoxy resins, Kaolin, Particulate composites, SPSS.

\section{Introduction}

The incorporation of particulate fillers into thermosets have a wide use in industry to extend the thermosets and to enhance specific features. Fillers usually improve the efficiency and quality of polymeric products. The degree of development relies on the filler origin, shape and particle size, and the volume or weight fraction of filler that will be chosen [1,2]. The addition of fillers to polymers is a quick and cheap way to change the features of the matrix materials. Hence, particulate filled polymer has been, and continue to be, the subject of growing interest in both modern technology and industrial research. In this way, strength, stiffness, toughness and fracture toughness, among other properties can be tailored to the desired values [3].
Epoxy resins are one of the most extensive thermoset materials in the world because of their valuable properties, large applications, inert chemical properties, barrier properties and low cost [4]. however, these materials exhibit a low elastic modulus, toughness, and fracture toughness. In this respect, a great deal of effort was devoted to the enhancement of the toughness of epoxy resins in the last few decades aiming at enlarging their field of applications [5].

Approaches to improve the toughness of epoxy resins involve mainly the incorporation of solid particles [6-9]. The most useful fillers in epoxy are glass fiber [10], silica powder and aramid fiber [11].

The present work reports the results of the incorporation of kaolin with different contents and different particle sizes into epoxy resins. Epoxy/kaolin composite was prepared by hand 
out method. In addition to, in this study, the mathematical models for influence of kaolin content and particle size on the flexural modulus, toughness, fracture toughness, hardness, and wear rate were created.

\section{Experimental Work}

\subsection{Materials}

\subsubsection{Preparation of Matrix Material}

The matrix material used for current work was Epoxy type (CY233) having density in range of $\left(1.1-1.2 \mathrm{~g} / \mathrm{cm}^{3}\right)$ at $25^{\circ} \mathrm{C}$ and its hardener was (HY956). Chemical structure of uncured epoxy is presented in Fig.1 [12].

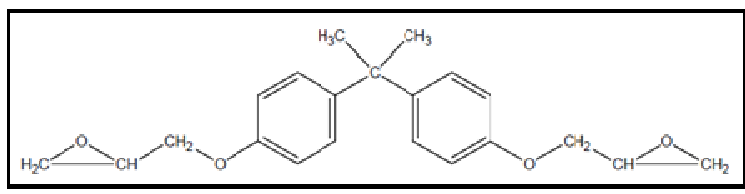

Fig. 1. Chemical Structure of uncured epoxy [12]

\subsubsection{Preparation of Reinforcement Material}

Raw Kaolin with a density of $2.64 \mathrm{~g} / \mathrm{cm}^{3}$, sourced from Iraqi National Company for Geological Survey and Refinery, was used as reinforcement in the current work. The kaolin powder was milled and sieved by a stack of sieves to obtain different particle sizes. The milled and sieved kaolin was then placed into a ceramic crucible and calcined in an electrical furnace at $700^{\circ} \mathrm{C}$ for $6 \mathrm{~h}$ to remove traces of moisture from the kaolin. Hence, the calcined kaolin powder was packaged in a sealed cellophane bag and kept in a desiccator. The typical composition and general properties of kaolin are presented in Tables 1, and 2 [13].

Table 1,

Chemical composition of kaolin [13]

\begin{tabular}{ll}
\hline Element & Wight \% \\
\hline $\mathrm{SiO}_{2}$ & 52.48 \\
$\mathrm{Al}_{2} \mathrm{O}_{3}$ & 31.31 \\
$\mathrm{Fe}_{2} \mathrm{O}_{3}$ & 2.094 \\
$\mathrm{TiO}_{2}$ & 1.43 \\
$\mathrm{MgO}$ & 0.33 \\
$\mathrm{Na}$ & 0.28 \\
$\mathrm{CaO}$ & 0.462 \\
L.O.I & 10.93 \\
\hline
\end{tabular}

Table 2,

General properties of kaolin [13].

\begin{tabular}{ll}
\hline Properties & Quantity \\
Density, g/cm & 2.64 \\
Powder color & White \\
Melting point, ${ }^{\circ} \mathrm{C}$ & 1755 \\
Fracture resistance & Higher $225 \mathrm{MPa}$ \\
Thermal properties & Endothermic at $260^{\circ} \mathrm{C}$ \\
& Isothermic at $980^{\circ} \mathrm{C}$ \\
\hline
\end{tabular}

\subsubsection{Preparation of Composites}

17 kaolin reinforced epoxy composite samples were prepared for the current study. Particle sizes of $(\mathrm{d}<8, \quad 18<\mathrm{d}<25, \quad 33<\mathrm{d}<45$, $50<\mathrm{d}<62 \mu \mathrm{m})$ with varying content of weight percent $(0,10,20,30,40 \% \mathrm{wt})$ of kaolin were used in making samples. Hand out method was used to prepare the composite in this work.

For preparation the samples, the required amounts of calcined kaolin and epoxy were mixed mechanically for $10 \mathrm{~min}$ to ensure suitable and even distribution of kaolin in the mixture phase. Afterward, Hardener was added in the ratio of 3:1 by weight of epoxy resin and gently but thoroughly stirred manually with the mixture for $15 \mathrm{~min}$ to obtain homogeneous mixture and to minimize the gas entrapment. The final mixture was gradually and gently poured into steel molds until the cavity of the molds was completely filled with the composite material. These molds were allowed to cure for $24 \mathrm{~h}$ at room temperature. After this, the sample was evacuated from the mold and post cured at $100^{\circ} \mathrm{C}$ for $4 \mathrm{hr}$. Finally, the sample was left to cool to lab temperature in the oven itself.

\subsection{Mechanical Tests 2.2.1. Flexural Test}

For the three-point flexural test, specimens were manufactured according to ASTM D790. The span to depth ratio of test samples was 32:1. The tests were performed by using universal testing machine with a crosshead speed of 0.5 $\mathrm{mm} / \mathrm{min}$. All the tests were made at room temperature. The flexural modulus $\mathrm{E}$ was calculated as follows [14]:

$E=\frac{m L^{3}}{4 D B^{3}}$

Where E: Young modulus (MPa), L: support span $(\mathrm{mm}), \mathrm{D}$ : width of sample $(\mathrm{mm}), \mathrm{B}$ : depth of sample (mm), and $\mathrm{m}$ : slope of the tangent to 
the initial straight line portion of the loaddeflection curve $(\mathrm{N} / \mathrm{mm})$ of deflection.

\subsubsection{Impact Test}

Impact specimens were manufactured according to ISO-179 standard suitable to Charpy Impact Instrument. Notch depth was equal for all specimens with $(1.5 \mathrm{~mm})$, and notch base radius was $(0.25 \mathrm{~mm})$. One edge of each specimen was polished so that crack could be readily discerned. The energy absorbed at fracture $(\mathrm{Uc})$ can be obtained from impact tests, from which, the value of toughness $(\mathrm{Gc})$ was calculated based on the following equation [14]:

$G_{c}=\frac{U_{c}}{B D \Phi}$

Where:

B is depth of sample (mm), D is width of sample $(\mathrm{mm}), \Phi$ is geometry function.

When the ratio between length of sample exposed to impact to cross section of sample equal to 4 , the geometry function $(\Phi)$ can be calculated from the following equation [14]:

$\Phi=0.135\left(\frac{\mathrm{a}}{\mathrm{D}}\right)^{-0.77}$

Where:

$\frac{a}{D}$ : Ratio of notch depth to cross section of sample.

In addition to, the values of fracture toughness $\mathrm{K}_{\mathrm{c}}$ can be calculated from the following equation [14]:

$K_{\mathrm{c}}=\left(\mathrm{EG}_{\mathrm{c}}\right)^{1 / 2}$

\subsubsection{Hardness Test}

The hardness tests, using Brinell hardness test instrument, were conducted at lab conditions and the measurements were performed at least three different locations on the samples, and the mean value was considered. The indenter was spherical ball with diameter of $5 \mathrm{~mm}$. The test load used in this test was $1500 \mathrm{~N}$ and maintained for $15 \mathrm{sec}$. The resulted diameter from the indentation was measured by microscope, and HB number was calculated as following [14]:
$\mathrm{HB}=\frac{2 \mathbf{P}}{\pi \mathrm{D}\left(\mathrm{D}-\left(\mathrm{D}^{2}-\mathrm{d}^{2}\right)^{05}\right)}$

Where: HB is Brinell value, $\mathrm{P}$ is applied load $(\mathrm{Kg}), \mathrm{D}$ is Ball diameter $(\mathrm{mm}), \mathrm{d}$ is Indention diameter on the sample surface $(\mathrm{mm})$

\subsubsection{Wear Test}

Wear test was done according to the ASTM G99 for dry sliding wear test by using a pin on drum tester instrument. The test was performed at a sliding speed of $2 \mathrm{~cm} / \mathrm{s}$ and pressure of $1 \mathrm{MPa}$ at ambient in room conditions. After the end of specified sliding distances $(50 \mathrm{~m})$, the testing device was stopped; the surfaces of samples were cleaned thoroughly with brush, and the surface particles (or debris) were removed and the weight loss was determined. The wear rate expressed in $(\mathrm{mg} / \mathrm{cm})$ of the material was calculated as follows:

$\mathbf{W} \cdot \mathbf{R}=\frac{\Delta w}{\mathrm{~S}}$

Where: W.R is wear rate, $\Delta \mathbf{W}$ is weight loss in $(\mathrm{mg})$, and $\mathbf{S}$ is sliding distance in $(\mathrm{m})$.

\subsection{Mathematical Modeling}

Regression model is a common statistical procedure used for modelling the relationship among several independent variables (variation factors) and a particular dependent (or response functions) variable of interest. Regression models can be used to save the time and the cost associated with the development and selection of new composite materials. The basic issue of model building in this project is to create a reliable relationship among mechanical properties and some factors affected on the resultant composite. The independent variables (explanatory factors) used in this work to predict the dependent variables, composite properties (E, Gc, Kc, HB, and WR), are presented in Table 3. The available experimental data (Table 4) were randomly divided into two groups; the training data group (Table 5) which found for prediction model building and the testing data group (Table 6) which found to test the flexibility and the validity of the prediction model. 
Table 3,

Definition and values of independent variables used in regression equation.

\begin{tabular}{lll}
\hline $\begin{array}{l}\text { Designations of independent } \\
\text { variable }\end{array}$ & Variable name & Value \\
\hline$x_{1}$ & kaolin concentration $(\% \mathrm{wt})$ & $0,10,20,30,40$ \\
$x_{2}$ & Particle size $(\mu \mathrm{m})$ & $\mathrm{d} \leq 8,18 \leq \mathrm{d} \leq 25,33<\mathrm{d}<45,50<\mathrm{d}<$ \\
& & 62 \\
\hline
\end{tabular}

Table 4,

Original experimental data for predicted and measured properties of epoxy composite.

\begin{tabular}{|c|c|c|c|c|c|c|c|c|c|c|c|c|}
\hline No. & $\begin{array}{l}\text { Kaolin } \\
\text { added } \\
(\%)\end{array}$ & $\begin{array}{l}\text { Particle } \\
\text { size } \\
(\mu \mathrm{m})\end{array}$ & $\begin{array}{l}\text { Measured } \\
\text { E (GPa) }\end{array}$ & $\begin{array}{l}\text { Predicted } \\
\text { E (GPa) }\end{array}$ & $\begin{array}{l}\text { Measured } \\
\mathbf{G}_{\mathbf{c}} \\
\left(\mathbf{K} \mathbf{J} / \mathbf{m}^{2}\right)\end{array}$ & $\begin{array}{l}\text { Predicted } \\
\mathbf{G}_{\mathbf{c}} \\
\left(\mathbf{K} \mathbf{J} / \mathbf{m}^{2}\right)\end{array}$ & $\begin{array}{l}\text { Measured } \\
\mathbf{K}_{\mathbf{c}} \\
(\mathbf{M P a} \sqrt{ } \mathbf{m})\end{array}$ & $\begin{array}{l}\begin{array}{l}\text { Predicted } \\
\mathbf{K}_{\mathbf{c}} \\
(\mathbf{M P a} \sqrt{ } \mathbf{m})\end{array} \\
\end{array}$ & $\begin{array}{l}\text { Measured } \\
\text { HB }\end{array}$ & $\begin{array}{l}\text { Predicted } \\
\text { HB }\end{array}$ & $\begin{array}{l}\begin{array}{l}\text { Measured } \\
\mathrm{WR} \\
(\mathrm{mg} / \mathrm{cm})\end{array} \\
\end{array}$ & $\begin{array}{l}\begin{array}{l}\text { Predicted } \\
\text { WR } \\
(\mathrm{mg} / \mathrm{cm})\end{array} \\
\end{array}$ \\
\hline 1 & 0 & 0 & 1.5 & 1.72652 & 1.16 & 1.09822 & 1.29 & 1.47088 & 13.02 & 13.12127 & 17.34 & 14.0044 \\
\hline 2 & 10 & $\mathrm{~d} \leq 8$ & 2.93 & 2.58406 & 1.55 & 1.52185 & 2.15 & 1.98661 & 17.12 & 16.71474 & 8.2 & 11.10932 \\
\hline 3 & 20 & $\mathrm{~d} \leq 8$ & 3.46 & 3.52369 & 1.95 & 2.12716 & 2.44 & 2.68983 & 19.49 & 21.72005 & 7.46 & 8.91932 \\
\hline 4 & 30 & $\mathrm{~d} \leq 8$ & 4.28 & 4.46332 & 2.63 & 2.73246 & 3.22 & 3.39305 & 26.55 & 26.72537 & 6.88 & 6.72932 \\
\hline 5 & 40 & $\mathrm{~d} \leq 8$ & 5.66 & 5.40295 & 3.5 & 3.33776 & 4.64 & 4.09627 & 33.89 & 31.73069 & 5.72 & 4.53931 \\
\hline 6 & 10 & $\begin{array}{l}18 \leq \mathrm{d} \\
\leq 25\end{array}$ & 2.77 & 2.44041 & 1.3 & 1.20393 & 2 & 1.65851 & 16.51 & 14.24399 & 8.98 & 10.43982 \\
\hline 7 & 20 & $\begin{array}{l}18 \leq \mathrm{d} \\
\leq 25\end{array}$ & 3.08 & 3.38005 & 1.82 & 1.80924 & 2.34 & 2.36173 & 18.43 & 19.24931 & 8.12 & 8.81419 \\
\hline 8 & 30 & $\begin{array}{l}18 \leq \mathrm{d} \\
\leq 25\end{array}$ & 4.11 & 4.31968 & 2.25 & 2.41454 & 2.99 & 3.06495 & 22.92 & 24.25463 & 7.22 & 7.18855 \\
\hline 9 & 40 & $\begin{array}{l}18 \leq \mathrm{d} \\
\leq 25\end{array}$ & 5.31 & 5.25931 & 3.11 & 3.01984 & 3.42 & 3.76817 & 29.09 & 29.25995 & 6.01 & 5.56291 \\
\hline 10 & 10 & $\begin{array}{l}33<d \\
<45\end{array}$ & 2.53 & 2.26598 & 1.12 & 0.81789 & 1.01 & 1.2601 & 13.13 & 11.2438 & 9.54 & 962686 \\
\hline 11 & 20 & $\begin{array}{l}33<d \\
<45\end{array}$ & 2.99 & 3.20561 & 1.35 & 1.42319 & 1.82 & 1.96332 & 15.44 & 16.24912 & 8.66 & 8.68653 \\
\hline 12 & 30 & $\begin{array}{l}33<d \\
<45\end{array}$ & 3.82 & 4.14524 & 1.78 & 2.02849 & 1.98 & 2.66654 & 19.79 & 21.25443 & 8.06 & 7.74619 \\
\hline 13 & 40 & $\begin{array}{l}33<d \\
<45\end{array}$ & 4.76 & 5.08487 & 2.15 & 2.6338 & 3.01 & 3.36976 & 25.35 & 26.25975 & 7.55 & 6.80586 \\
\hline 14 & 10 & $\begin{array}{l}50<d \\
<62\end{array}$ & 1.58 & 2.09155 & 0.79 & 0.43184 & 0.99 & 0.86169 & 9.62 & 8.24361 & 9.97 & 8.8139 \\
\hline 15 & 20 & $\begin{array}{l}50<d \\
<62\end{array}$ & 2.87 & 3.03118 & 1.18 & 1.03714 & 1.41 & 1.56491 & 12.98 & 13.24892 & 8.87 & 8.55887 \\
\hline 16 & 30 & $\begin{array}{l}50<d \\
<62\end{array}$ & 3.95 & 3.97081 & 1.47 & 1.64245 & 2.11 & 2.26813 & 17.35 & 18.25424 & 8.11 & 8.30384 \\
\hline 17 & 40 & $\begin{array}{l}50<d \\
<62\end{array}$ & 4.43 & 4.91044 & 1.88 & 2.24775 & 2.89 & 2.97135 & 21.78 & 23.25956 & 7.21 & 8.04881 \\
\hline
\end{tabular}

Table 5,

Training data for properties of epoxy composite.

\begin{tabular}{|c|c|c|c|c|c|c|c|c|c|c|c|c|}
\hline No. & $\begin{array}{l}\text { Kaolin } \\
\text { added } \\
(\%)\end{array}$ & $\begin{array}{l}\text { Particle } \\
\text { size } \\
(\mu \mathrm{m})\end{array}$ & $\begin{array}{l}\text { Measured } \\
\mathbf{E} \text { (GPa) }\end{array}$ & $\begin{array}{l}\text { Predicted } \\
\text { E (GPa) }\end{array}$ & $\begin{array}{l}\text { Measured } \\
\mathbf{G}_{\mathrm{c}} \\
\left(\mathbf{K} \mathbf{J} / \mathbf{m}^{2}\right)\end{array}$ & $\begin{array}{l}\text { Predicted } \\
\mathbf{G}_{\mathrm{c}} \\
\left(\mathbf{K} \mathbf{J} / \mathbf{m}^{2}\right)\end{array}$ & $\begin{array}{l}\text { Measured } \\
\mathbf{K}_{\mathbf{c}} \\
(\mathbf{M P a} \sqrt{ } \mathbf{m})\end{array}$ & $\begin{array}{l}\text { Predicted } \\
\mathbf{K}_{\mathbf{c}} \\
\left(\mathbf{M P a} \sqrt{ }_{\mathbf{m}}\right)\end{array}$ & $\begin{array}{l}\text { Measured } \\
\text { HB }\end{array}$ & $\begin{array}{l}\text { Predicted } \\
\text { HB }\end{array}$ & $\begin{array}{l}\text { Measured } \\
\text { WR }\end{array}$ & $\begin{array}{l}\text { Predicted } \\
\text { WR }\end{array}$ \\
\hline 1 & 0 & 0 & 1.5 & 1.72652 & 1.16 & 1.09822 & 1.29 & 1.47088 & 13.02 & 13.12127 & 17.34 & 14.0044 \\
\hline 2 & 10 & $\mathrm{~d} \leq 8$ & 2.93 & 2.58406 & 1.55 & 1.52185 & 2.15 & 1.98661 & 17.12 & 16.71474 & 8.2 & 11.10932 \\
\hline 3 & 20 & $\mathrm{~d} \leq 8$ & 3.46 & 3.52369 & 1.95 & 2.12716 & 2.44 & 2.68983 & 19.49 & 21.72005 & 7.46 & 8.91932 \\
\hline 4 & 30 & $\mathrm{~d} \leq 8$ & 4.28 & 4.46332 & 2.63 & 2.73246 & 3.22 & 3.39305 & 26.55 & 26.72537 & 6.88 & 6.72932 \\
\hline 5 & 40 & $\mathrm{~d} \leq 8$ & 5.66 & 5.40295 & 3.5 & 3.33776 & 4.64 & 4.09627 & 33.89 & 31.73069 & 5.72 & 4.53931 \\
\hline 6 & 10 & $\begin{array}{l}18 \leq \mathrm{d} \\
\leq 25\end{array}$ & 2.77 & 2.44041 & 1.3 & 1.20393 & 2 & 1.65851 & 16.51 & 14.24399 & 8.98 & 10.43982 \\
\hline 7 & 20 & $\begin{array}{l}18 \leq \mathrm{d} \\
\leq 25\end{array}$ & 3.08 & 3.38005 & 1.82 & 1.80924 & 2.34 & 2.36173 & 18.43 & 19.24931 & 8.12 & 8.81419 \\
\hline 8 & 30 & $\begin{array}{l}18 \leq \mathrm{d} \\
\leq 25\end{array}$ & 4.11 & 4.31968 & 2.25 & 2.41454 & 2.99 & 3.06495 & 22.92 & 24.25463 & 7.22 & 7.18855 \\
\hline 9 & 40 & $\begin{array}{l}18 \leq \mathrm{d} \\
\leq 25\end{array}$ & 5.31 & 5.25931 & 3.11 & 3.01984 & 3.42 & 3.76817 & 29.09 & 29.25995 & 6.01 & 5.56291 \\
\hline
\end{tabular}


Table 6,

Testing data for properties of epoxy composite.

\begin{tabular}{|c|c|c|c|c|c|c|c|c|c|c|c|c|}
\hline No. & $\begin{array}{l}\text { Kaolin } \\
\text { added } \\
(\%)\end{array}$ & $\begin{array}{l}\text { Particle } \\
\text { size } \\
(\mu \mathrm{m})\end{array}$ & $\begin{array}{l}\text { Measured } \\
\text { E (GPa) }\end{array}$ & $\begin{array}{l}\text { Predicted } \\
\text { E (GPa) }\end{array}$ & $\begin{array}{l}\text { Measured } \\
\mathbf{G}_{\mathbf{c}} \\
\left(\mathbf{K} \mathbf{J} / \mathbf{m}^{2}\right)\end{array}$ & $\begin{array}{l}\text { Predicted } \\
\mathbf{G}_{\mathbf{c}} \\
\left(\mathbf{K} \mathbf{J} / \mathbf{m}^{2}\right)\end{array}$ & $\begin{array}{l}\text { Measured } \\
\mathbf{K}_{\mathbf{c}} \\
(\mathbf{M P a} \sqrt{ } \mathbf{m})\end{array}$ & $\begin{array}{l}\text { Predicted } \\
\mathbf{K}_{\mathbf{c}} \\
(\mathbf{M P a} \sqrt{ } \mathbf{m})\end{array}$ & $\begin{array}{l}\text { Measured } \\
\text { HB }\end{array}$ & $\begin{array}{l}\text { Predicted } \\
\text { HB }\end{array}$ & $\begin{array}{l}\text { Measured } \\
\text { WR }\end{array}$ & $\begin{array}{l}\text { Predicted } \\
\text { WR }\end{array}$ \\
\hline 1 & 10 & $\begin{array}{l}33<d \\
<45\end{array}$ & 2.53 & 2.26598 & 1.12 & 0.81789 & 1.01 & 1.2601 & 13.13 & 11.2438 & 9.54 & 962686 \\
\hline 2 & 20 & $\begin{array}{l}33<d \\
<45\end{array}$ & 2.99 & 3.20561 & 1.35 & 1.42319 & 1.82 & 1.96332 & 15.44 & 16.24912 & 8.66 & 8.68653 \\
\hline 3 & 30 & $\begin{array}{l}33<d \\
<45\end{array}$ & 3.82 & 4.14524 & 1.78 & 2.02849 & 1.98 & 2.66654 & 19.79 & 21.25443 & 8.06 & 7.74619 \\
\hline 4 & 40 & $\begin{array}{l}33<d \\
<45\end{array}$ & 4.76 & 5.08487 & 2.15 & 2.6338 & 3.01 & 3.36976 & 25.35 & 26.25975 & 7.55 & 6.80586 \\
\hline 5 & 10 & $\begin{array}{l}50<d \\
<62\end{array}$ & 1.58 & 2.09155 & 0.79 & 0.43184 & 0.99 & 0.86169 & 9.62 & 8.24361 & 9.97 & 8.8139 \\
\hline 6 & 20 & $\begin{array}{l}50<d \\
<62\end{array}$ & 2.87 & 3.03118 & 1.18 & 1.03714 & 1.41 & 1.56491 & 12.98 & 13.24892 & 8.87 & 8.55887 \\
\hline 7 & 30 & $\begin{array}{l}50<d \\
<62\end{array}$ & 3.95 & 3.97081 & 1.47 & 1.64245 & 2.11 & 2.26813 & 17.35 & 18.25424 & 8.11 & 8.30384 \\
\hline 8 & 40 & $\begin{array}{l}50<d \\
<62\end{array}$ & 4.43 & 4.91044 & 1.88 & 2.24775 & 2.89 & 2.97135 & 21.78 & 23.25956 & 7.21 & 8.04881 \\
\hline
\end{tabular}

\section{Results and Discussion}

\subsection{Experimental Work}

\subsubsection{Flexural Modulus}

Figure 2 shows the variation of flexural modulus of the material with kaolin filler content for different particle sizes. Generally, the flexural modulus (E) is referred to the relative stiffness of composite [15]. Thus, the growing in $\mathrm{E}$ value with increasing filler loading is expected since the addition of filler improves the stiffness of composites. This enhancing can be attributed to the stiff nature of filler. A similar observation was made by many researchers [13, 16-17].

The rate of increasing in $\mathrm{E}$ values was comparable to the increasing in weight fraction of kaolin and the decrease in particle size. Therefore, it was conformed that the total area available to deformation stress played an important role. The increasing in $\mathrm{E}$ values is mainly attributed to the restriction of chain mobility, this can be explained by plastic deformation mechanism. Capability of any material to plastic deformation is mainly specified by the mobility of the molecular chain (molecular motion) to occur under applied force. The existence of solid particles like kaolin in this case has restricted the mobility of the molecular chain to pass each other and the orientation that consequently resulted in increase in rigidity (stiffness).

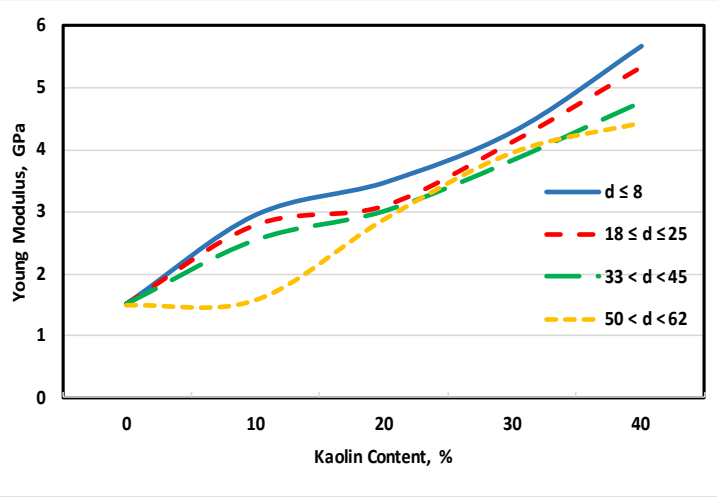

Fig. 2. Variation in flexural modulus of different particle sizes and weight fractions of kaolin

\subsubsection{Toughness and Fracture Toughness}

The variation of toughness $\left(\mathrm{G}_{\mathrm{c}}\right)$ and fracture toughness $\left(\mathrm{K}_{\mathrm{c}}\right)$ for the composites with filler loading for different particle sizes are presented in figures (3, and 4), respectively. It can be seen that the $G_{c}$ and $K_{c}$ increases, as the kaolin content increases and the particle size decreases. The maximum improvement is attained with $40 \%$ wt kaolin and $(\mathrm{d}<8 \mu \mathrm{m})$ particle size, and represents more than (203) \% and (259) \% in comparison with $\mathrm{G}_{\mathrm{c}}$ and $\mathrm{K}_{\mathrm{c}}$ of neat resin, respectively

The improvement of impact properties was reported in literature with different modifier [16, $18]$. 


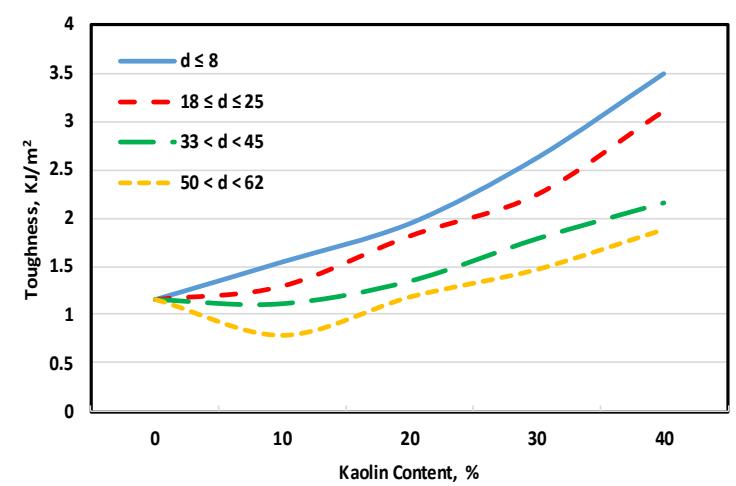

Fig. 3. Variation in toughness of different particle sizes and weight fractions of kaolin

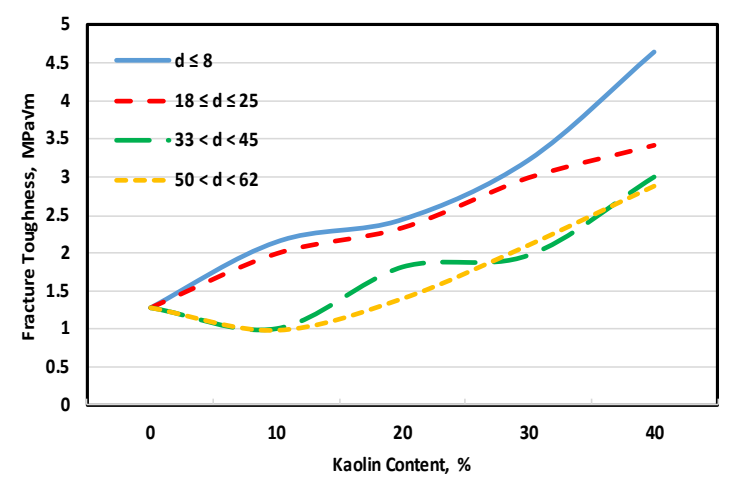

Fig. 4. Variation in fracture toughness of different particle sizes and weight fractions of kaolin

The $\mathrm{G}_{\mathrm{c}}$ and $\mathrm{K}_{\mathrm{c}}$ improvement by the addition of kaolin particles can be due to the formation of small sized crystallites, i.e. spherulites, and the capacity to absorb much energy by the enlarge of portion of matrix. Also, this enhancing can be explained by the crack pinning mechanism [19]. Impact strength is an indication of tolerability for a sudden impact. As the composites are exposed to the impact load, rapid crack propagation is initiated through the material. When such crack propagation encounters solid particles in the filled composite, the filler can absorb the energy and stop the crack propagation. In other hand, Nakagawa and Sano [20] have shown the existence of small and fine particles dispersed into the matrix makes plastic deformation more easy. So, during the fracture of the composite in which the solid filler is fine and well dispersed, i.e., in which the material is more homogeneous, the stress will have to be bigger to begin a micro crack on particles and the impact energy will strongly be absorbed by plastic deformation. Hence, finer particles lead to better impact properties of the composite.

On the other hand, the increasing of the kaolin content to higher levels (beyond 40\%wt) may be brought the inverse effects on the properties because of the brittleness problem.

\subsubsection{Hardness}

It is clearly seen from Figure (5) that the hardness increases with the decrease in particle size and increase in weight percent of filler. The addition of kaolin filler improves the hardness value of composite material because of the increasing in the resistance strength of polymer to plastic deformation. The results agree well with those obtained by Saleh and Mustafa [13], who showed that the hardness increases with increasing weight percent and decreasing particle size.

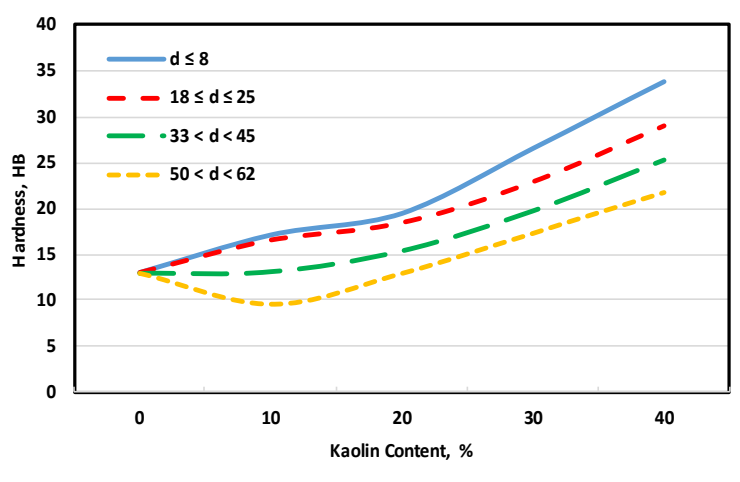

Fig. 5. Variation in hardness of different particle sizes and weight fractions of kaolin

\subsubsection{Wear Rate}

The results presented in Fig. (6) show that the wear rate was less when reinforcing the epoxy resin with kaolin particles in the range of (0-40\%). This enhancement may be explained by that the kaolin particles will absorb a portion of applied stress and heat generated by friction as a result of slip between the surface of samples and the surface of the rotating disk. Thus, the applied stress and heat generated will be distributed on the matrix and reinforcing particles, and this will improve the ability of the epoxy resin to resist the wear.

Also, the same trend was observed with the decrease in the particle size. This is because the increasing in particle size increases the interface 
surface and this leads to impede the process of transfer of stresses and heat of the matrix to the reinforcing particles, and then increases the concentration of stress, heat, thus this will increase the wear rate with increasing the particle size.

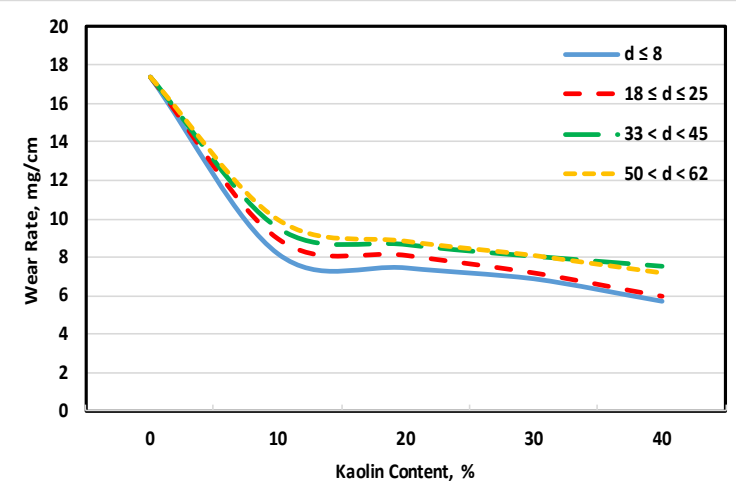

Fig. 6. Variation in wear rate of different particle sizes and weight fractions of kaolin

\subsection{Results and Discussion of Mathematical Model}

Regression models of composite properties were developed from the processing of experimental results. These analyses were performed by using SPSS software. The following equations represent the relationship between composite properties and all independent variables involved in this work:

$\mathrm{E}=1.727+0.094 X_{1}-0.01 x_{2} \quad \ldots(7)$ $\mathrm{G}_{\mathrm{o}}=1.098+0.061 x_{1}-0.023 X_{2} \quad \ldots(8)$

$\mathrm{K}_{\mathrm{c}}=1.471+0.7 X_{1}-0.023 X_{2} \quad \ldots(9)$

$\mathrm{HB}=13.121+0.501 X_{1}-0.176 X_{2} \ldots(10)$

$W . R=14.004-0.251 X_{1}-0.088 X_{2}+0.004 X_{1} X_{2}$

Where:

$E$ : flexural modulus, $G_{c}$ : toughness, $K_{c}$ : fracture toughness.

All equations confirmed a high value of multiple correlation coefficient $\mathrm{R}$ which were $(0.981,0.989,0.953,0.976$, and 0.851$)$ for equations $(7,8,9,10 \& 11)$ respectively.

The error value of the training data group was $(7.25 \%, 4.72 \%, 8.84 \%, 5.13 \%$, and $14.43 \%)$ for (E, Gc, Kc, HB, and WR), respectively and for the testing data group was $(10.29 \%, 19.42 \%$, $14.18 \%, 7.73 \%$, and $5.51 \%$ ) for (E, Gc, Kc, HB, and WR), respectively.
This reveals that the statistical model could predict the epoxy composite properties with about $(92.75 \%, 95.28 \%, 91.16 \%, 94.87 \%$, and $85.57 \%$ ) accuracy of the training data set and approximately $(89.71 \%, 80.58 \%, 85.82 \%$, $92.27 \%$, and $94.49 \%$ ) accuracy of the testing data set for properties (E, Gc, Kc, HB, and WR), respectively.

Figures (5, 6, 7, 8, and 9) present the comparison between the predicted and experimental values of 17 original data for mechanical properties, respectively by (SPSS) package.

It can be noticed from these figures that the predicted values are in a close match with the experimental values for all properties.

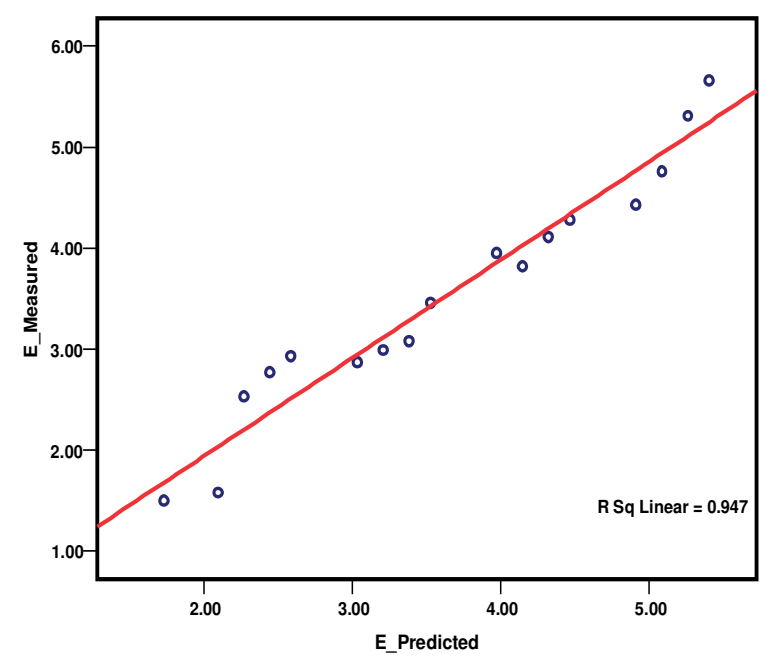

Fig. 7. Experimental and predicted values of flexural modulus

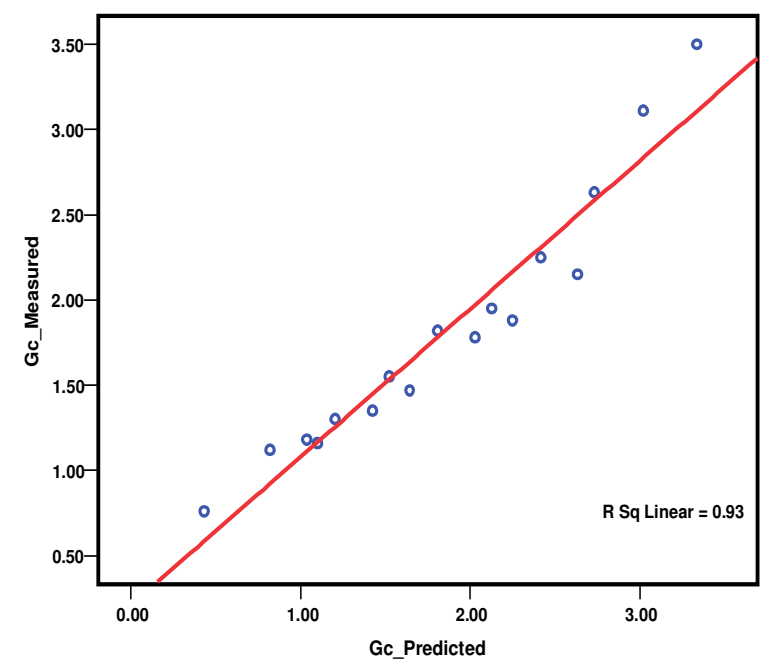

Fig. 8. Experimental and predicted values of toughness 


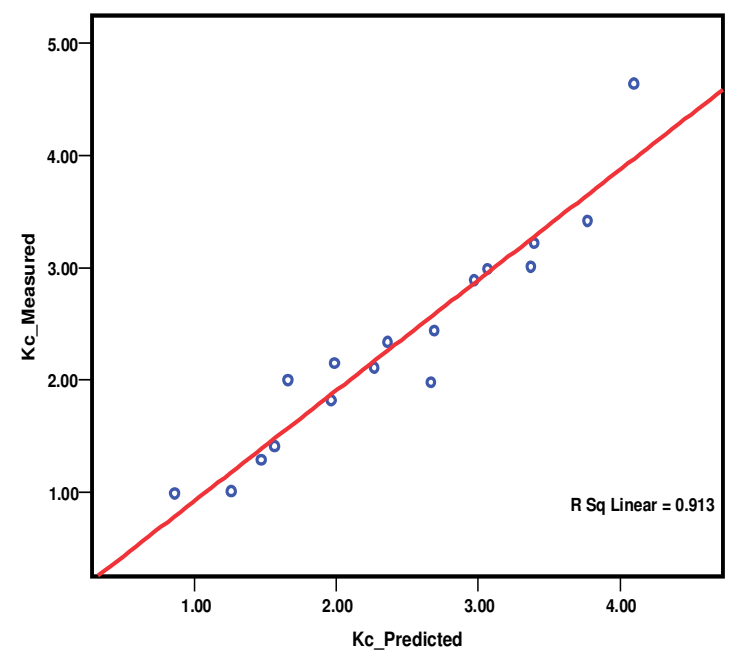

Fig. 9. Experimental and predicted values of fracture toughness

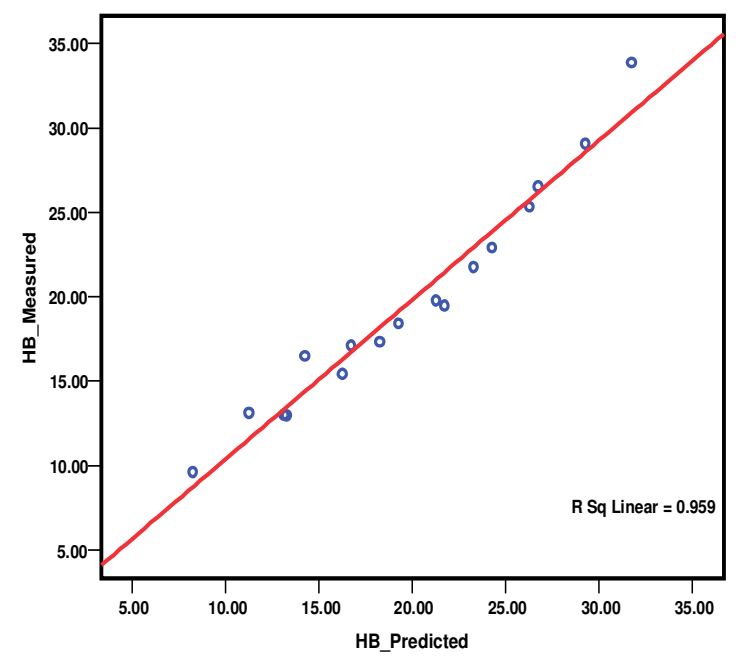

Fig. 10. Experimental and predicted values of hardness

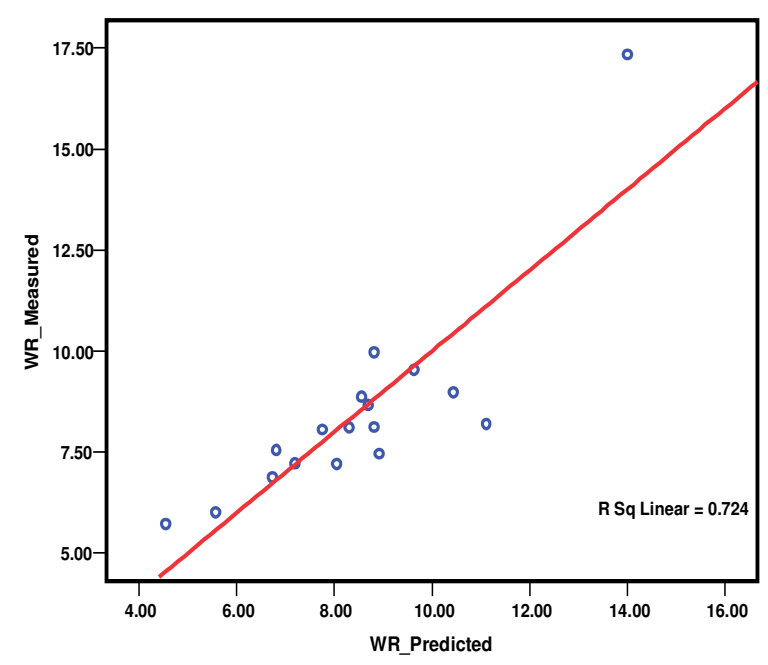

Fig. 11. Experimental and predicted values of wear rate.

\section{Conclusions}

From the experimental results it can conclude the following:

- The addition of kaolin particles into epoxy resin can remarkably alter the material's mechanical properties. The material properties (E, Gc, Kc, HB, and WR) increase with the increasing filler content.

- The properties of epoxy composite decreased as the particle size of kaolin increased.

- The multiple regression models could predict the properties of epoxy composite with higher accuracy for different kaolin additions, and particle sizes.

\section{References}

[1]Y. Wang, and J.J. Wang, (1999), "Shear yield behavior of calcium carbonate-filled polypropylene", Polymer Eng. \& Sci., vol. 39, No.1, pp. 190-198.

[2] I. Plesa, P. V. Notingher, S. Schlögl, C. Sumereder, and M. Muhr, (2016), "Properties of Polymer Composites Used in HighVoltage Applications “, Polymer Journal, vol. 8, No. 126, pp. 1-63.

[3]E. G. Guerica, J. I. Eguiazabal, and J. Nazabal, (1998), "Influence of molding conditions and talc content on the properties of polypropylene composites", European Polymer Journal, vol. 34, No. 98, pp. 12131219.

[4] M. S. Bhatnagar, (1993), "Epoxy resins from 1980 to date", Part 1, Polymer-Plastics Technolgy and Eng. Journal, vol. 32, No. 12, pp. 53-113.

[5] S. R. Lu, X. E. L. Xiao, L. Pan, F. Z. Tan, and J. H. Yu, (2014), "Enhanced thermal and mechanical properties of epoxy composites by mixing thermotropic liquid crystalline epoxy grafted graphene oxide", eXPRESS Polymer Letters, vol.8, No.7, pp. 467-479.

[6] A. C. Moloney, H. H. Kausch, and H. R. Stieger, (1983), "The Fracture of ParticulateFilled Epoxy Resin", Journal of Materials Science, vol. 18, No. 1, pp. $208-216$.

[7] J. Spanoudakis, and R., J. Young, (1984), "Crack Propagation in a Glass ParticulateFilled Epoxy Resin", Journal of Materials Science, vol. 19, No. 2, pp. 473 - 486.

[8] S. Fellahi, N. Chikhi, and M. Bakar, (2001), "Modification of Epoxy Resin with Kaolin as 
a Toughening Agent", Journal of Applied Polymer Sci., vol. 82, No. 4, pp. $861-878$.

[9]B. M. Deya'a, F. M. Hussien, and I. G. Dway, (2011), "Studying the Impact Strength of (Epoxy with $\mathrm{TiO} 2$ and $\mathrm{MgO}$ ) Composite", Eng. and Tech. Journal, vol. 29, No. 10, pp. 1971-1978.

[10] J. A. Bennet, and R. J. Young, (1998), “The effect of fiber-matrix adhesion upon crack bridging in fiber reinforced composites", Composites Part A: Applied Science and Manufacturing, vol. 29, No. 9-10, pp. 10711081

[11] V. A. Alvarez, M. E Valdez, and A. Vasquez, (2003), "Dynamic mechanical properties and interphase fiber/matrix evaluation of unidirectional glass fiber/epoxy composites,", Polymer Testing, vol. 22, No. 6, pp. 611-615.

[12] D. K Shukla, and R. K. Srivastava, (2011), "Effect of Alumina Platelet Reinforcement on Dynamic Mechanical Properties of Epoxy", Proceedings of the World Congress on Engineering, London, U.K, Vol III.

[13] N. J. Saleh, and S. N. Mustafa, (2011), " A Study of Some Mechanical, Thermal and Physical Properties of Polymer Blend with Iraqi Kaolin Filler", Eng. and Tech. Journal, vol. 29, No. 11, pp. 2114-2131.
[14] A. M. Hameed, (2000), "Study of the Effect of Reinforcement with Fibers on Some Physical Characteristics of Composite Material", M.Sc. Thesis, University of Technology.

[15] V. Shah, (2007), "Handbook of Polymer Testing and Failure Analysis", 3rd edition, New Jersey, John Wily \& Sons, Inc., 648.

[16] H. V. Ramakrishna, and S. K. Rai, (2006), "Utilization of Granite Powder as a Filler for Polybutylene Terepthalate Toughened Epoxy Resin", Journal of Minerals \& Materials Characterization \& Engineering, Vol. 5, No.1, pp 1-19.

[17] E. Suryani, E. S. Abdul Rashid, K. Ariffin, and C. C. Kooi, (2006), "The Flexural and Morphological Properties of $\alpha$-Alumina Filled Epoxy Composites", Malaysian Polymer Journal, Vol 1, No. 1, pp. 25-38.

[18] S. Bose, and P. A. Mahanwar, (2004), "Effect of Particle Size of Filler on Properties of Nylon-6", Journal of Minerals \& Materials Characterization \& Engineering, Vol. 3, No.1, pp. 23-31.

[19] F. F. Lange, and K. C. Radford, (1971), "Fracture Energy of an Epoxy Composite System", Journal of Materials Science, vol. 6, No, 9, pp.1197-1203.

[20] H.Nakagawa, and H.Sano, (1982), Polym. Prepr., Vol. 26, p.249. 


\section{تقييم الخواص الميكانيكية لمتراكبات الايبوكسي المقواة_دقائق الكاؤولين

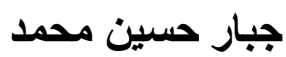

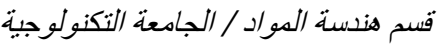 \\ البريد الاكتروني: Jabbaraljanaby@yahoo.com}

\section{الخلاصة}

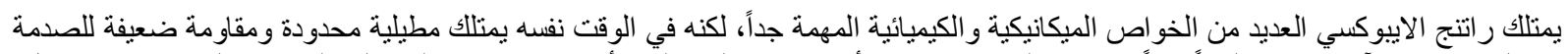

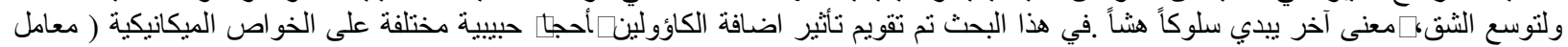

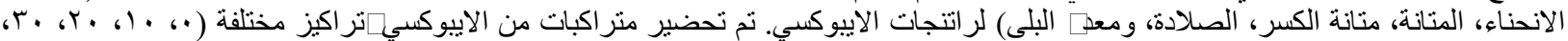

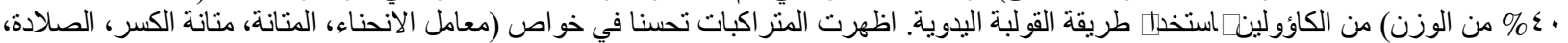

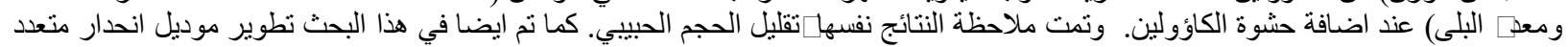

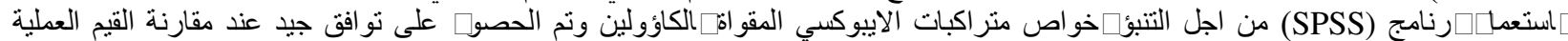

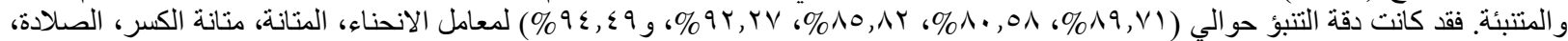
ومعدَ البلى على التو الي. 